\title{
Establishment of a pancreatic stem cell line from fibroblast-derived induced pluripotent stem cells
}

\author{
Takashi Kuise ${ }^{1}$, Hirofumi Noguchi ${ }^{2 *}$, Hiroshi Tazawa', Takashi Kawai ${ }^{1}$, Masaya Iwamuro ${ }^{3}$, Issei Saitoh", \\ Hitomi Usui Kataoka ${ }^{5}$, Masami Watanabe ${ }^{6}$, Yasufumi Noguchi ${ }^{7}$ and Toshiyoshi Fujiwara ${ }^{1}$
}

\author{
* Correspondence: \\ n.hirofumi@cehpnet.com \\ 2Department of Surgery, Chiba-East \\ National Hospital, National Hospital \\ Organization, Chiba 260-8712, Japan \\ Full list of author information is \\ available at the end of the article
}

\begin{abstract}
Background: For cell therapies to treat diabetes, it is important to produce a sufficient number of pancreatic endocrine cells that function similarly to primary islets. Induced pluripotent stem (iPS) cells represent a potentially unlimited source of functional pancreatic endocrine cells. However, the use of iPS cells for laboratory studies and cell-based therapies is hampered by their high tumorigenic potential and limited ability to generate pure populations of differentiated cell types in vitro. The purpose of this study was to establish a pancreatic stem cell line from iPS cells derived from mouse fibroblasts.

Methods: Mouse iPS cells were induced to differentiate into insulin-producing cells by a multi-step differentiation protocol, which was conducted as described previously with minor modifications. Selection of the pancreatic stem cell was based on morphology and Pdx1 expression. The pancreatic potential of the pancreatic stem cells was evaluated using a reverse transcription $P C R$, real-time PCR, immunofluorescence, and a glucose challenge test. To assess potential tumorigenicity of the pancreatic stem cells, the cells were injected into the quadriceps femoris muscle of the left hindlimb of nude mice.

Results: The iPS-derived pancreatic stem cells expressed the transcription factor -Pdx $1-a$ marker of pancreatic development, and continued to divide actively beyond passage 80 . Endocrine cells derived from these pancreatic stem cells expressed insulin and pancreatic genes, and they released insulin in response to glucose stimulation. Mice injected with the pancreatic stem cells did not develop tumors, in contrast to mice injected with an equal number of iPS cells.
\end{abstract}

Conclusion: This strategy provides a new approach for generation of insulin-producing cells that is more efficient and safer than using iPS cells. We believe that this approach will help to develop a patient-specific cell transplantation therapy for diabetes in the near future.

Keywords: Mouse pancreatic stem cells, Diabetes, iPS cells

\section{Background}

Production of a sufficient number of insulin-producing cells from stem cells that function similarly to primary islets is important for clinical application of stem cell therapy to diabetes. Many studies have reported the differentiation of insulin-producing cells from mouse embryonic stem (ES) cells and, more recently, from human ES cells [1-7]. Unfortunately, these methods involving ES cells have various limitations such as ethical issues during the generation of the cells and immunological rejection after an

(c) 2014 Kuise et al.; licensee BioMed Central Ltd. This is an Open Access article distributed under the terms of the Creative Commons Attribution License (http://creativecommons.org/licenses/by/4.0), which permits unrestricted use, distribution, and reproduction in any medium, provided the original work is properly credited. The Creative Commons Public Domain Dedication waiver (http://creativecommons.org/publicdomain/zero/1.0/) applies to the data made available in this article, unless otherwise stated. 
allogeneic transplant. Induced pluripotent stem (iPS) cell technology has the potential to generate patient-specific cell types including functional pancreatic endocrine cells [8-11]. However, the use of ES and iPS cells for laboratory studies and cell-based therapies is hampered by their high tumorigenic potential and limited ability to generate pure populations of differentiated cell types in vitro.

D'Amour et al. developed a 5-step protocol for differentiation of human ES cells into pancreatic hormone-expressing cells in 2006 [12]; this method represented a great step forward in regenerative medicine; however, the use of ES cells in clinical practice is problematic, as explained above. We and other groups have established mouse pancreatic stem cell lines using specific culture conditions [13-15]. We have also demonstrated that young mice have a high number of pancreatic stem cells that can be isolated, but older mice have a low number of pancreatic stem cells, and therefore are unable to provide viable clones [16]. Similarly, human pancreatic stem cells cannot be isolated from 20- to 60-year-old donors [17].

In this study, we established a pancreatic stem cell line from mouse iPS cells, which have the potential for self-renewal and multipotency to generate both endocrine and exocrine pancreatic cells.

\section{Methods}

\section{Culture conditions}

Mouse iPS cells (iPS-MEF-Ng-20D-17) were provided by the RIKEN BRC through the Project for Realization of Regenerative Medicine and the National Bio-Resource Project of MEXT, Japan [18]. Undifferentiated iPS cells were maintained on mouse embryo fibroblast feeder layers (STO cell line) in Dulbecco's modified Eagle medium (DMEM; SigmaAldrich, St Louis, MO, USA) supplemented with 15\% (vol/vol) fetal bovine serum (FBS; Millipore, Billerica, MA, USA), 1\% nonessential amino acids (Millipore), 1\% nucleosides (Millipore), 1\% penicillin/streptomycin (Sigma-Aldrich), $110 \mu \mathrm{M}$ 2-mercaptoethanol (Life Technologies, Tokyo, Japan), and $500 \mathrm{U} / \mathrm{mL}$ leukemia inhibitory factor (LIF; Millipore) at $37^{\circ} \mathrm{C}$. Cultures were manually passaged at a 1:4-1:8 split ratio every $3-5$ days.

Directed differentiation into insulin-producing cells was conducted as described previously [12], with minor modifications (Figure 1). At stage 1, cells were incubated with $25 \mathrm{ng} / \mathrm{mL}$ Wnt3a and $100 \mathrm{ng} / \mathrm{mL}$ activin A (R\&D Systems, Minneapolis, MN, USA) in the RPMI medium (Life Technologies) at $37^{\circ} \mathrm{C}$ for 1 day, followed by treatment with $100 \mathrm{ng} /$ $\mathrm{mL}$ activin $\mathrm{A}$ in RPMI (containing $0.2 \% \mathrm{FBS}$ ) at $37^{\circ} \mathrm{C}$ for 2 days. At stage 2, the cells were incubated with $50 \mathrm{ng} / \mathrm{mL}$ FGF10 (R\&D Systems) and $0.25 \mu \mathrm{M}$ KAAD-cyclopamine (Toronto Research Chemicals, Toronto, Ontario, Canada) in RPMI (containing 2\% FBS) at $37^{\circ} \mathrm{C}$ for 3 days. At stage 3, the cells were incubated with $50 \mathrm{ng} / \mathrm{mL}$ fibroblast growth factor 10 (FGF10), $0.25 \mu \mathrm{M}$ KAAD-cyclopamine, and $2 \mu \mathrm{M}$ all-trans retinoic acid (Sigma-Aldrich) in DMEM with a 1\% (vol/vol) B27 supplement (Life Technologies) at $37^{\circ} \mathrm{C}$ for 3 days. At stage 4 , the cells were treated with $1 \mu \mathrm{M} \mathrm{N}$-[N-(3,5-Difluorophenacetyl)-L-alanyl]-S-phenylglycine t-butyl ester (DAPT; Sigma-Aldrich) and $50 \mathrm{ng} / \mathrm{mL}$ exendin-4 (Sigma-Aldrich) in DMEM with a $1 \%$ (vol/vol) B27 supplement at $37^{\circ} \mathrm{C}$ for 3 days. At stage 5 , the cells were incubated with $50 \mathrm{ng} / \mathrm{mL}$ exendin-4, $50 \mathrm{ng} / \mathrm{mL}$ IGF-1 (Sigma), and $50 \mathrm{ng} / \mathrm{mL}$ hepatocyte growth factor (HGF; R\&D Systems) in the CMRL medium (Life technologies) with a $1 \%(\mathrm{vol} / \mathrm{vol}) \mathrm{B} 27$ supplement at $37^{\circ} \mathrm{C}$ for $3-6$ days. 


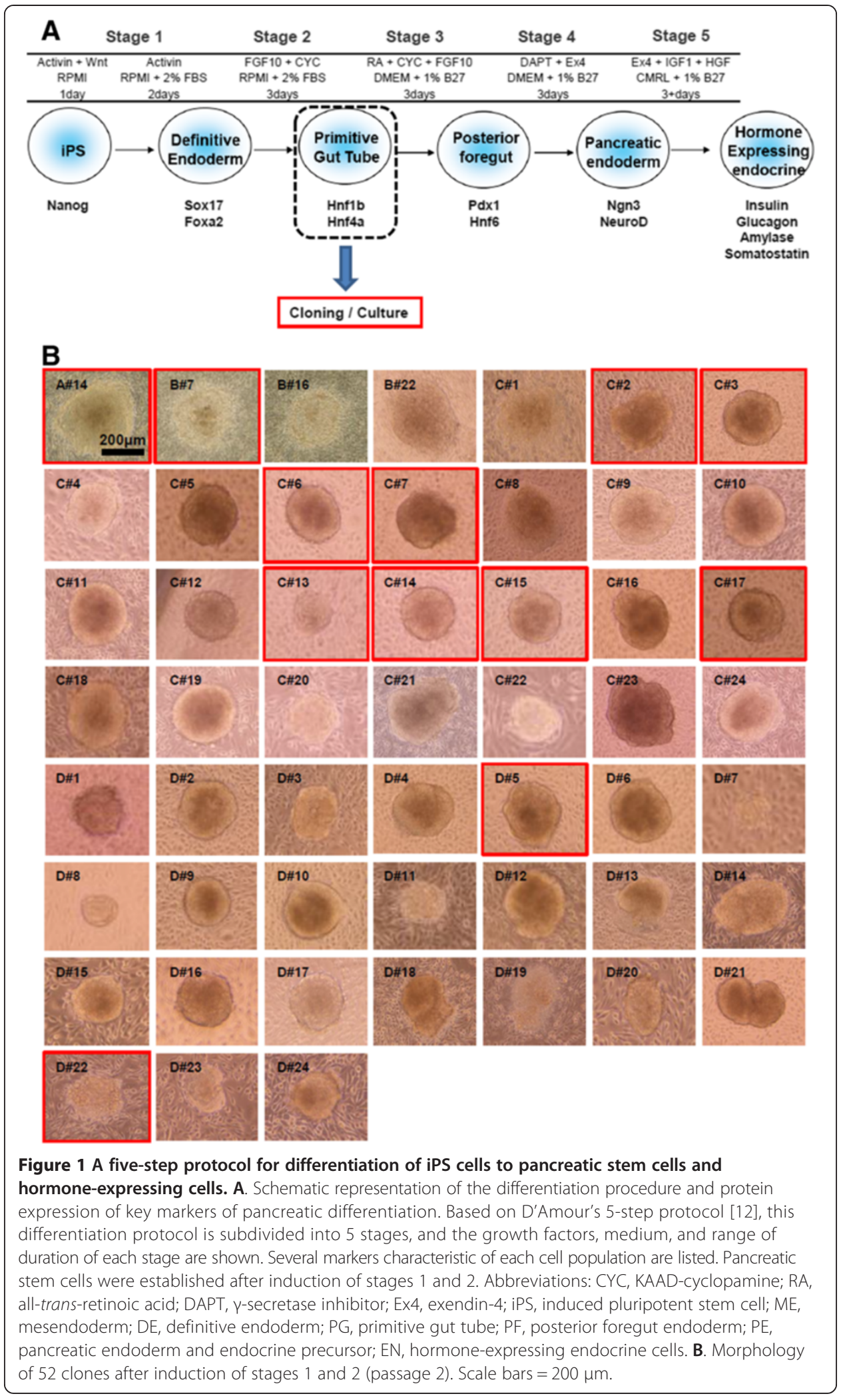




\section{Tumorigenesis assay}

To examine the potential tumorigenicity of candidate clones at passage $50,1 \times 10^{7}$ cells were injected into the quadriceps femoris muscle of the left hindlimb of nude mice $(\mathrm{n}=3)$. As a positive control, we transplanted $1 \times 10^{7}$ iPS cells into the right hindlimb. All mouse studies were approved by the Institutional Animal Care and Use Committee of Okayama University (Reference number: OKU-2011351).

\section{Semi-quantitative RT-PCR}

Total RNA was extracted from cells using the RNeasy Mini Kit (Qiagen, Tokyo, Japan). After the RNA was quantified using spectrophotometry, $2.5 \mu \mathrm{g}$ of the RNA was heated at $85^{\circ} \mathrm{C}$ for $3 \mathrm{~min}$ and then reverse-transcribed into cDNA in a $25-\mu \mathrm{L}$ reaction containing 200 units of Superscript III RT (Life Technologies), 50 ng of random hexamer primers (Life Technologies), $160 \mu \mathrm{mol} / \mathrm{L} \mathrm{dNTP}$, and $10 \mathrm{nmol} / \mathrm{L}$ dithiothreitol. The reaction consisted of $10 \mathrm{~min}$ at $25^{\circ} \mathrm{C}, 60 \mathrm{~min}$ at $42^{\circ} \mathrm{C}$, and $10 \mathrm{~min}$ at $95^{\circ} \mathrm{C}$. PCRs were performed in a Perkin-Elmer 9700 Thermocycler with $3 \mu \mathrm{L}$ of cDNA (20 ng RNA equivalent), $160 \mu \mathrm{mol} / \mathrm{L}$ cold dNTPs, $10 \mathrm{pmol}$ of the appropriate oligonucleotide primers, $1.5 \mathrm{mmol} / \mathrm{L} \mathrm{MgCl}_{2}$, and 5 units of AmpliTaq Gold DNA polymerase (PerkinElmer, Waltham, MA, USA). The oligonucleotide primers and cycle numbers used for semi-quantitative PCR are shown in Table 1. The thermal cycle profile used a 10-min denaturing step at $94 \mathrm{C}$ followed by the amplification cycles $(1 \mathrm{~min}$ denaturation at 94 $\mathrm{C}, 1 \mathrm{~min}$ annealing at $57 \mathrm{C}$, and $1 \mathrm{~min}$ extension at $72^{\circ} \mathrm{C}$ ), with a final extension step of $10 \mathrm{~min}$ at $72^{\circ} \mathrm{C}$. The steps taken to validate these measurements were previously reported [19].

\section{TaqMan real-time PCR}

Quantification of Ngn3, NeuroD, and insulin-2 mRNA levels was conducted using the TaqMan real-time PCR system according to the manufacturer's instructions (Life Technologies). PCR consisted of 40 cycles including $2 \mathrm{~min}$ at $50^{\circ} \mathrm{C}$ and $10 \mathrm{~min}$ at $95^{\circ} \mathrm{C}$ as initial steps. In each cycle, denaturation was performed for $15 \mathrm{~s}$ at $95^{\circ} \mathrm{C}$ and annealing/ extension was $1 \mathrm{~min}$ at $60^{\circ} \mathrm{C}$. PCR was conducted in $20-\mu \mathrm{L}$ reaction containing cDNA synthesized from 1,500 ng of total RNA. Standard curves were constructed using cDNA generated from total RNA isolated from primary mouse islets. For each sample, the expression of Ngn3, NeuroD, and insulin-2 was normalized against the $\beta$-actin expression level. Mouse Ngn3, NeuroD, and insulin-2 and $\beta$-actin primers were obtained commercially (Assays-on-Demand Gene Expression Products; Life Technologies).

Table 1 List of gene-specific primers

\begin{tabular}{ll}
\hline Gene & Forward/Reverse $\mathbf{p r i m e r}\left(\mathbf{5}^{\prime} \rightarrow \mathbf{3}^{\prime}\right)$ \\
\hline Nanog & cacaggctcttcttcagattg/ttttgcttgctcttcacattgg \\
$\mathrm{Pdx} 1$ & cggacatctccccatacg/aaagggagctggacgcgg \\
Insulin-2 & tccgctacaatcaaaaaccat/gctgggtagtggtgggtcta \\
Glucagon & agaagggcagagcttgggcc/tgctgcctggccctccaagt \\
Amylase & tggccttctggatcttgc/aaaggtctgcttccttggg \\
Somatostatin & atgctgtcctgccgtctc/ttctctgtctggttgggctc \\
Gapdh & accacagtccatgccatcac/tccaccaccctgttgctgta \\
\hline
\end{tabular}




\section{The glucose challenge}

To remove insulin added to the culture medium, cultured cells were washed 10 times with phosphate-buffered saline (PBS). The RPMI medium with a low glucose concentration $(2.8 \mathrm{mM})$ was added, and the cells were cultured at $37^{\circ} \mathrm{C}$ for $30 \mathrm{~min}$ as preincubation. After the preincubation, RPMI with a low glucose concentration (2.8 mM) was added, and the cells were cultured at $37^{\circ} \mathrm{C}$ for $60 \mathrm{~min}$. This lowglucose medium was then collected. The RPMI medium with a high glucose concentration $(20 \mathrm{mM})$ was then added, and the cells were cultured at $37^{\circ} \mathrm{C}$ for $60 \mathrm{~min}$. This high-glucose medium was also collected. The collected media were assayed for insulin concentration using an enzyme-linked immunosorbent assay (ELISA; SRL, Tokyo, Japan).

\section{An immunofluorescence assay}

Cells were fixed in $4 \%$ paraformaldehyde for $20 \mathrm{~min}$. Subsequently, the cells were blocked with $10 \%$ serum and $0.2 \%$ Triton X-100 in PBS, and then incubated with a primary antibody against mouse insulin (guinea pig polyclonal antibody to mouse insulin, 1:100; Abcam, Tokyo, Japan) overnight at $4^{\circ} \mathrm{C}$. The cells were next incubated with a secondary antibody (goat polyclonal antibody against guinea pig IgG, H\&L labeled with fluorescein isothiocyanate [FITC], 1:100; Abcam). A medium for fluorescence microscopy that contained 4',6-diamidino-2-phenylindole (DAPI; Vector Laboratories, Burlingame, CA, USA) was used for mounting onto slides.

\section{Results}

Directed pancreatic differentiation of fibroblast-derived iPS cells

To generate pancreatic stem cells from iPS cells, we applied the D'Amour's protocol [12]. At stage 1, iPS cells differentiated into definitive endoderm using high concentrations of activin A with Wnt3a (day 1) and FBS supplementation (days 2-3). At stage 2 , the definitive endoderm cells differentiated into gut tube endoderm through removal of activin A and addition of FGF10 and KAAD-cyclopamine. After the cells were passaged once and cultured for 4 days, the clones were manually picked under a dissecting microscope (Figure 1A). These clones were then cultured on STO feeder cells in the ES culture medium. The 52 clones were cultured and passaged for 30 days (Figure 1B). After the 30-day culture of these clones, 12 clones were still viable (Figure 2A),

\section{Establishment of pancreatic stem cells}

Among the 12 clones, 6 were eliminated because they did not proliferate as actively as did the iPS cells. Expression of pancreatic and duodenal homeobox factor 1 (Pdx1) mRNA, a transcription factor required for pancreatic development and $\beta$-cell maturation, in the remaining 6 clones is shown in Figure 2B. The proliferative activity of 4 of the 6 clones significantly decreased during a 60-day culture after the isolation. Therefore, we selected the 2 clones (C\#15 and D\#22) that maintained a constant cell proliferation rate as candidate clones for differentiation into pancreatic stem cells. Clone C\#15 was ascertained to have a tumorigenic potential. Finally, clone D\#22 was selected (Figure 2C). D\#22 cells did not express green fluorescent protein (GFP), whereas the 


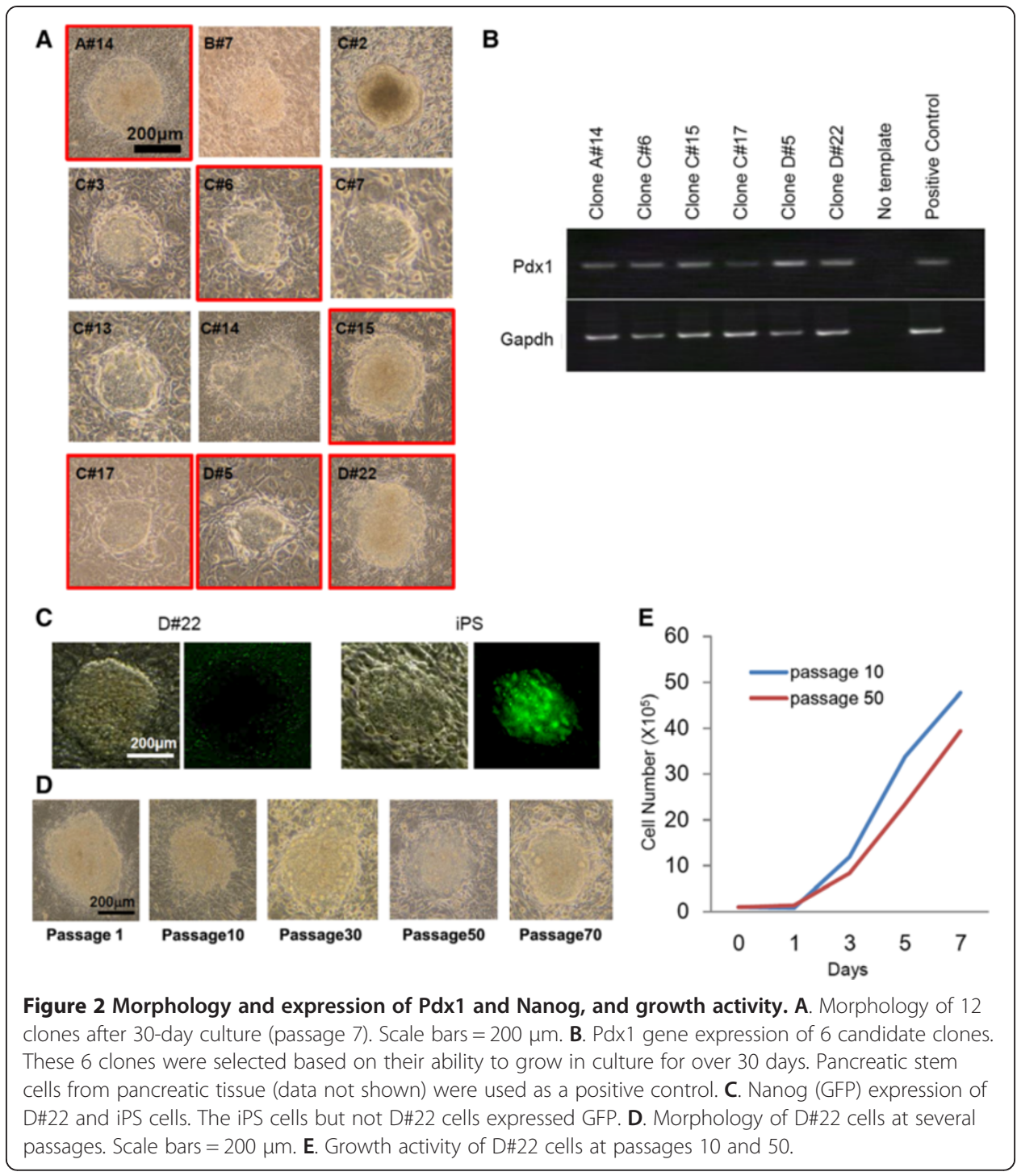

iPS cells in this study expressed GFP according to Nanog expression [18]; this result suggests that D\#22 cells do not express Nanog and are therefore different from iPS cells (Figure 2C).

Morphology, gene expression, and growth activity of the pancreatic stem cell line D\#22 Clone D\#22 formed a flat "cobblestone" monolayer, which is characteristic of cultured duct cells [20]. D\#22 cells continued to divide actively beyond passage 80 (over 6 months) without changes in morphology (Figure 2D) or in growth activity (Figure 2E). We performed normal and quantitative RT-PCR testing of clone D\#22 for ES cell markers, endodermal/pancreatic progenitor cell markers, and pancreatic cell markers. Mouse pancreas cDNA and iPS cells were used as controls. Representative genes of the posterior foregut (Pdx1) and pancreatic endoderm (Ngn3, NeuroD) were expressed by clone D\#22, whereas genes typically expressed in undifferentiated iPS cells (Nanog) and in pancreatic tissue (insulin, glucagon, amylase, and somatostatin) were not expressed in D\#22 (Figure 3A, B). 


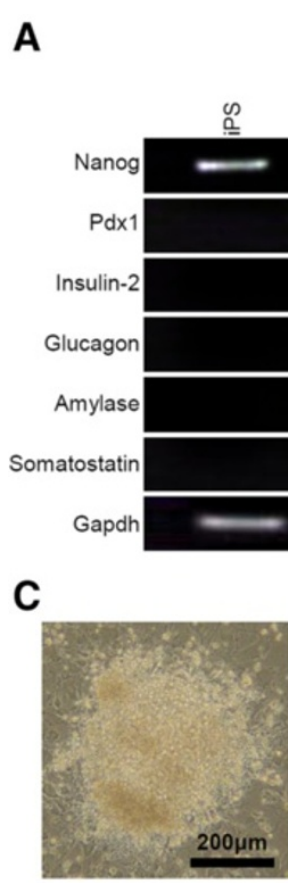

$\mathrm{D} \# 22$ stage 5

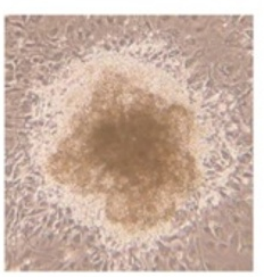

iPS stage 5
D

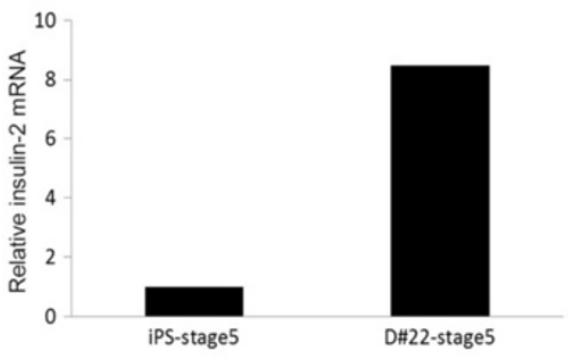

B
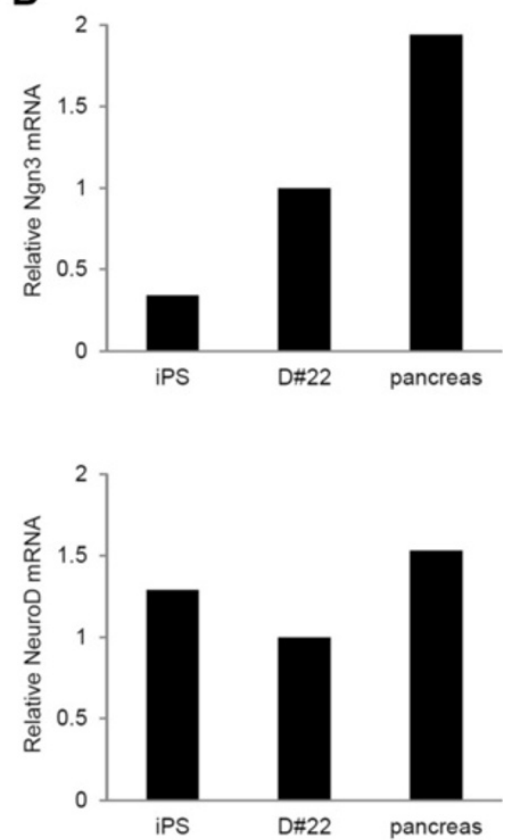

E

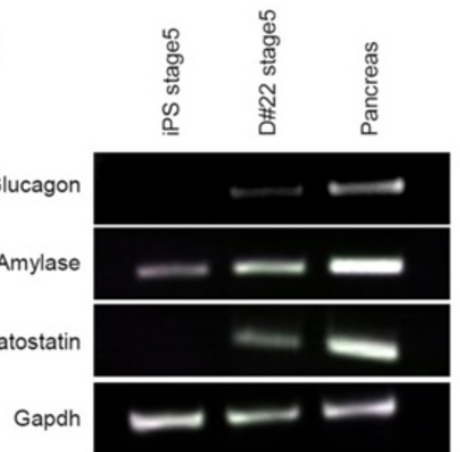

Figure 3 Characterization of the pancreatic stem cell line D\#22. A. RT-PCR analysis of expression of an ES cell marker (Nanog), pancreatic progenitor markers (Pdx1), and mature pancreatic markers (insulin-2, glucagon, amylase, and somatostatin) in D\#22 cells. Pancreatic cells and iPS cells were used as controls. The primers used for RT-PCR are shown in Table 1. B. Quantitative RT-PCR analysis of the Ngn3 and NeuroD genes in iPS, D\#22, and pancreatic cells. The data are expressed as the Ngn3 and NeuroD to $\beta$-actin ratio, with the expression in D\#22 cells arbitrarily set at 1.0. C. Morphology of D\#22 stage 5 cells and iPS stage 5 cells. Scale bars $=200 \mu \mathrm{m}$. D. Quantitative RT-PCR analysis of the insulin-2 gene in D\#22 stage 5 cells and iPS stage 5 cells. Differentiated cells derived from D\#22 cells by stages $3-5$ or iPS cells by stages $1-5$ were analyzed using quantitative RT-PCR. The data are expressed as the insulin- 2 to $\beta$-actin ratio, with the expression in iPS stage 5 cells arbitrarily set at 1.0. E. RT-PCR testing for pancreatic markers of maturity (glucagon, amylase, and somatostatin) in D\#22 stage 5 and iPS stage 5 cells. Pancreatic cells were used as a control. The primers used for RT-PCR are shown in Table 1.

The differentiation capacity of the pancreatic stem cell line D\#22

For differentiation of D\#22 cells into insulin-producing cells, the following protocols were used (stages 3-5 in Figure 1A). At the final stage of differentiation, D\#22 cells underwent a morphological transition (Figure 3C). The differentiated cells derived from D\#22 cells, named D\#22 stage 5 cells, were tested for pancreas-specific gene expression and insulin production. Mouse iPS cells were also induced to differentiate using the 5 -step protocol (Figure 1); the pancreatic potential of the final product (iPS stage 5 
cells) was compared with that of D\#22 stage 5 cells. Quantitative PCR demonstrated that levels of insulin 2 mRNA were 8.46-fold higher in D\#22 stage 5 cells than in iPS stage 5 cells (Figure 3D). D\#22 stage 5 cells were positive for gene expression of hormones produced in the endocrine pancreas (e.g., insulin, glucagon, and somatostatin) in addition to a representative enzyme produced in the exocrine pancreas (amylase; Figure 3E).

\section{Insulin expression and functional analysis of $\mathrm{D \# 22}$ stage 5 cells}

To determine whether D\#22 cells could differentiate into insulin-producing cells, immunofluorescence analysis was performed. Some D\#22 stage 5 cells were positive for insulin, and the insulin-positive cells were $\mathrm{C}$-peptide positive, thus excluding the possibility of insulin uptake from the medium (Figure 4A).

To evaluate the insulin production of D\#22 stage 5 cells, a glucose challenge test was performed in vitro. The amount of insulin secreted by D\#22 stage 5 cells tended to increase when the glucose concentration of the medium was high, whereas iPS stage 5 cells showed little or no response to the glucose challenge (Figure 4B). These data suggested that D\#22 stage 5 cells had the ability to secrete insulin in response to the pathological glucose concentrations similar to those in diabetic patients.

\section{Tumorigenicity of the pancreatic stem cell line D\#22}

To rule out the possibility of teratoma formation as a result of contamination with iPS cells or spontaneous transformation of D\#22 cells, the tumorigenic potential was tested in vivo. $\mathrm{D} \# 22$ cells $\left(1 \times 10^{7}\right)$ at passage 50 were transplanted into nude mice $(\mathrm{n}=3)$, and no tumors developed after 2 months. In contrast, injection of $1 \times 10^{7}$ iPS cells resulted in tumor development after 2 weeks. Tumors derived from the iPS cells became larger over time and had a size of $40 \mathrm{~mm}$ at 2 months after transplantation (Figure $4 \mathrm{C}$ ).

\section{Discussion}

In this study, we established a pancreatic stem cell line, D\#22, from mouse fibroblastderived iPS cells. Generally, stem cells are defined as cells capable of self-renewal that can develop into various lineages in the body. D\#22 cells were maintained by repeated passaging for more than 6 months without growth inhibition, which indicates that D\#22 cells have the potential for self-renewal. The differentiated D\#22 stage 5 cells express insulin, glucagon, amylase, and somatostatin mRNA; these data indicate that $\mathrm{D} \# 22$ cells can generate both endocrine and exocrine pancreatic lineages. Consequently, we consider the clone D\#22 a pancreatic stem cell line. As shown in Figure 3A, D\#22 cells express Pdx1, Ngn3, and NeuroD. Pdx1-expressing epithelial progenitors are involved in the development of organs during embryogenesis, especially the cells giving rise to the endocrine, exocrine, and ductal cells of the pancreas [21]. Ngn3 is expressed in all endocrine progenitors [21], initiating a cascade of expression of transcription factors that control endocrine cell differentiation. NeuroD, a basic helix-loop-helix (bHLH) transcription factor, is also a key regulator of pancreatic islet morphogenesis and insulin gene transcription [22,23]. However, D\#22 cells did not express key transcription factors of ES cells (Nanog) or mature pancreatic cells (insulin, glucagon, 


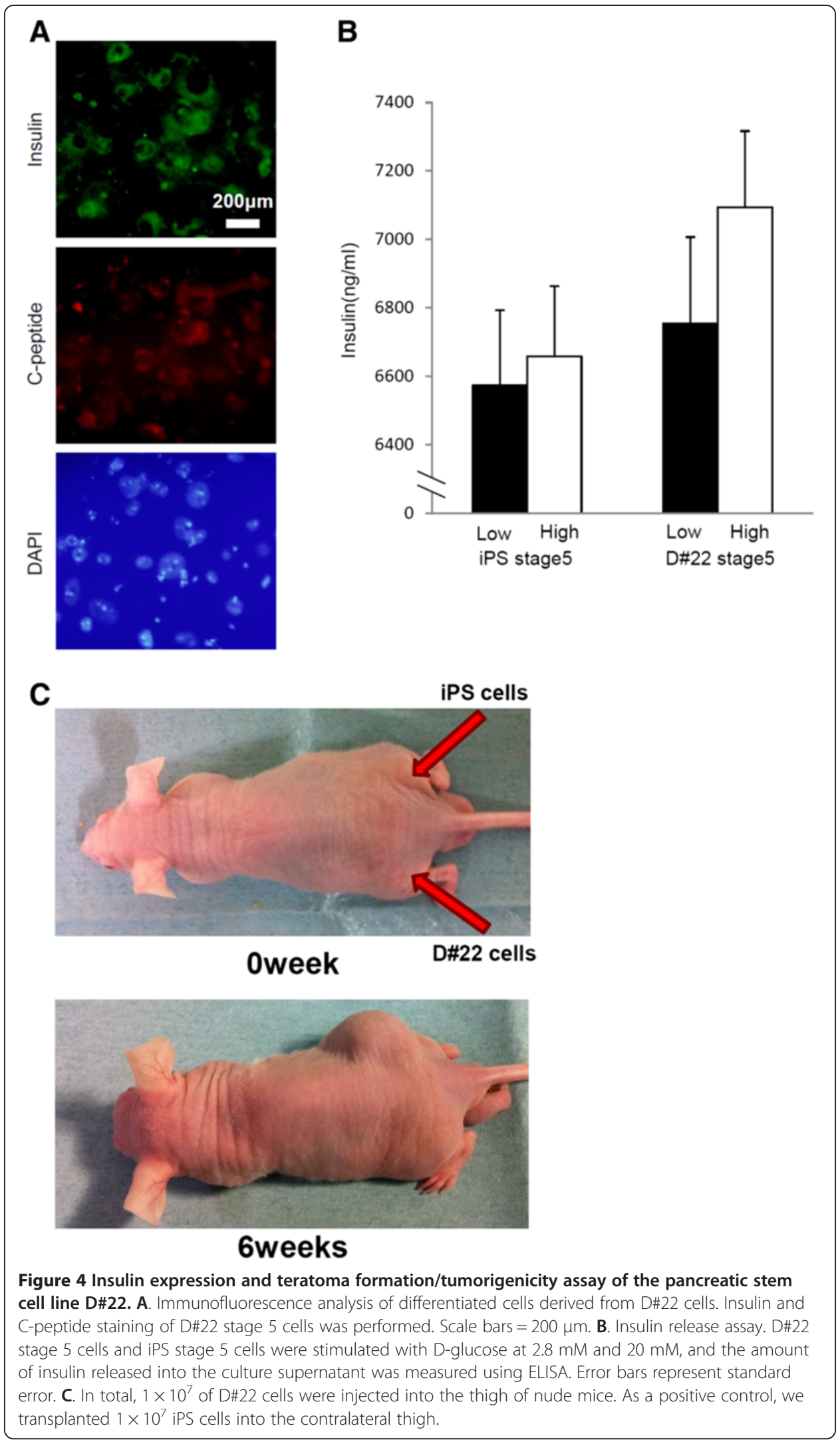


amylase, and somatostatin). These data indicate that $\mathrm{D} \# 22$ cells have the characteristics of pancreatic endoderm-committed intermediates or pancreatic progenitors.

D\#22 stage 5 cells secreted insulin in response to glucose stimulation, and immunofluorescent analysis of the differentiated cells showed production of insulin and C-peptide. Moreover, in the real-time PCR analysis, mRNA expression of insulin 2 was 8.46-fold higher in D\#22 stage 5 cells than in iPS stage 5 cells generated using the same stepwise differentiation protocol. In addition, clone D\#22 is not tumorigenic, whereas transplanted iPS cells rapidly form tumors. In general, tumorigenesis is a major concern in the clinical application of stem cell therapy. Therefore, we can conclude that D\#22 cells are potentially a more useful cell source for $\beta$-cell replacement therapy in diabetes than iPS cells because the former are safer and capable of generating greater numbers of functional insulin-producing cells. Nevertheless, the level of insulin expression was still low; suggesting that the induced cells were still immature. Therefore, it is necessary to develop a more efficient differentiation protocol for production of insulin-producing cells.

The advantages of D\#22 cells compared with iPS cells are 1) more efficient differentiation, and 2) no teratoma formation. Recently, a self-renewing endodermal progenitor (EP) cell line generated from human ES and iPS cells was reported [24]. The selfrenewing EP cells display morphological properties and a gene expression pattern characteristic of a definitive endoderm. These EP cells differentiate into pancreatic cells, hepatocytes, and intestinal epithelial cells. Moreover, EP cells are not tumorigenic in vivo. D\#22 cells may be similar to EP cells, but are likely to be differentiated further into the pancreatic linage because they express the Pdx1, Ngn3, and NeuroD transcription factors.

\section{Conclusions}

We established a mouse pancreatic stem cell line from iPS cells derived from mouse embryonic fibroblasts. This clonal cell line has the ability of self-renewal and efficiently differentiates into insulin-producing cells without any signs of tumorigenesis. Therefore, this strategy provides a new approach for generation of insulin-producing cells more efficiently and safely compared to iPS cells. We believe that this approach will help implement a patient-specific cell transplantation therapy for diabetic patients in the near future.

\footnotetext{
Abbreviations

DAPI: 4',6-diamidino-2-phenylindole; DAPT: N-[N-(3,5-Difluorophenacetyl)-L-alanyl]-S-phenylglycine t-butyl ester; DMEM: Dulbecco's modified Eagle medium; ES: Embryonic stem, FBS, fetal bovine serum; FGF10: Fibroblast growth factor 10; FITC: Fluorescein isothiocyanate; Foxa2: Forkhead box protein a2; GFP: Green fluorescent protein; HGF: Hepatocyte growth factor; IGF-1: Insulin-like growth factor 1; iPS: Induced pluripotent stem; LIF: Leukemia inhibitory factor; MEXT: Ministry of Education, Culture, Sports, Science, and Technology of Japan; Pdx1: Pancreatic and duodenal homeobox factor 1.

Competing interests

The authors declare that they have no competing interests.

TK carried out most of the experimental work with the help of. HT, TK, MI. HN designed the experiments and analyzed the data. IS, HUK, MW, YN and TF provided materials and discussion. TK and HN wrote the manuscript. All authors discussed and commented on the manuscript. All authors read and approved the final manuscript.
} 


\begin{abstract}
Author details
'Department of Gastroenterological Surgery, Okayama University Graduate School of Medicine, Dentistry and Pharmaceutical Sciences, Okayama 700-8558, Japan. ${ }^{2}$ Department of Surgery, Chiba-East National Hospital, National Hospital Organization, Chiba 260-8712, Japan. ${ }^{3}$ Department of Gastroenterology and Hepatology, Okayama University Graduate School of Medicine, Dentistry, and Pharmaceutical Sciences, Okayama 700-8558, Japan. ${ }^{4}$ Department of Pediatric Dentistry, Niigata University Graduate School of Medical and Dental Sciences, Niigata 951-8514, Japan. ${ }^{5}$ Department of Primary Care and Medical Education, Okayama University Graduate School of Medicine, Dentistry and Pharmaceutical Sciences, Okayama 700-8558, Japan. ${ }^{6}$ Department of Urology, Okayama University Graduate School of Medicine, Dentistry and Pharmaceutical Sciences, Okayama 700-8558, Japan. ${ }^{7}$ Department of Socio-environmental Design, Hiroshima International University, Hiroshima 737-0112, Japan.
\end{abstract}

Received: 2 April 2014 Accepted: 23 May 2014

Published: 27 May 2014

\title{
References
}

1. Bonner-Weir S, Weir GC: New sources of pancreatic beta-cells. Nat Biotechnol 2005, 23(7):857-861.

2. Madsen OD: Stem cells and diabetes treatment. APMIS 2005, 113(11-12):858-875.

3. Assady S, Maor G, Amit M, Itskovitz-Eldor J, Skorecki KL, Tzukerman M: Insulin production by human embryonic stem cells. Diabetes 2001, 50(8):1691-1697.

4. Segev H, Fishman B, Ziskind A, Shulman M, Itskovitz-Eldor J: Differentiation of human embryonic stem cells into insulin-producing clusters. Stem Cells 2004, 22(3):265-274.

5. Baharvand H, Jafary H, Massumi M, Ashtiani SK: Generation of insulin-secreting cells from human embryonic stem cells. Dev Growth Differ 2006, 48(5):323-332.

6. Xu X, Kahan B, Forgianni A, Jing P, Jacobson L, Browning V, Treff N, Odorico J: Endoderm and pancreatic islet lineage differentiation from human embryonic stem cells. Cloning Stem Cells 2006, 8(2):96-107.

7. Kwon YD, Oh SK, Kim HS, Ku SY, Kim SH, Choi YM, Moon SY: Cellular manipulation of human embryonic stem cells by TAT-PDX1 protein transduction. Mol Ther 2005, 12(1):28-32.

8. Takahashi K, Tanabe K, Ohnuki M, Narita M, Ichisaka T, Tomoda K, Yamanaka S: Induction of pluripotent stem cells from adult human fibroblasts by defined factors. Cell 2007, 131(5):861-872.

9. Yu J, Vodyanik MA, Smuga-Otto K, Antosiewicz-Bourget J, Frane JL, Tian S, Nie J, Jonsdottir GA, Ruotti V, Stewart R, Slukvin II, Thomson JA: Induced pluripotent stem cell lines derived from human somatic cells. Science 2007, 318(5858):1917-1920.

10. Park IH, Arora N, Huo H, Maherali N, Ahfeldt T, Shimamura A, Lensch MW, Cowan C, Hochedlinger K, Daley GQ: Disease-specific induced pluripotent stem cells. Cell 2008, 134(5):877-886.

11. Dimos JT, Rodolfa KT, Niakan KK, Weisenthal LM, Mitsumoto H, Chung W, Croft GF, Saphier G, Leibel R, Goland R, Wichterle $H$, Henderson CE, Eggan K: Induced pluripotent stem cells generated from patients with ALS can be differentiated into motor neurons. Science 2008, 321(5893):1218-1221.

12. D'Amour KA, Bang AG, Eliazer S, Kelly OG, Agulnick AD, Smart NG, Moorman MA, Kroon E, Carpenter MK, Baetge EE: Production of pancreatic hormone-expressing endocrine cells from human embryonic stem cells. Nat Biotechnol 2006, 24(11):1392-1401.

13. Noguchi H, Oishi K, Ueda M, Yukawa H, Hayashi S, Kobayashi N, Levy MF, Matusmoto S: Establishment of mouse pancreatic stem cell line. Cell Transplant 2009, 18(5):563-571.

14. Yamamoto T, Yamato E, Taniguchi H, Shimoda M, Tashiro F, Hosoi M, Sato T, Fujii S, Miyazaki Jl: Stimulation of cAMP signaling allows isolation of clonal pancreatic precursor cells from adult mouse pancreas. Diabetologia 2006, 49(10):2359-2367.

15. Noguchi H, Saitoh I, Kataoka HU, Watanabe M, Noguchi Y, Fujiwara T: Culture conditions for mouse pancreatic stem cells. Cell Med 2013, 5(2-3):63-68.

16. Kuise T, Noguchi H, Saitoh I, Kataoka HU, Watanabe M, Noguchi Y, Fujiwara T: Isolation efficiency of mouse pancreatic stem cells is age-dependent. Cell Med 2013, 5(2-3):69-73.

17. Noguchi H, Naziruddin B, Jackson A, Shimoda M, Ikemoto T, Fujita Y, Chujo D, Takita M, Kobayashi N, Onaca N, Hayashi S, Levy MF, Matsumoto S: Characterization of human pancreatic progenitor cells. Cell Transplant 2010, 19(6):879-886.

18. Okita K, Ichisaka T, Yamanaka S: Generation of germline-competent induced pluripotent stem cells. Nature 2007, 448(7151):313-317.

19. Noguchi $\mathrm{H}$, Iwanaga $Y$, Okitsu $T$, Nagata $H$, Yonekawa $Y$, Matsumoto $S$ : Evaluation of islet transplantation from non-heart beating donors. Am J Transplant 2006, 6(10):2476-2482.

20. Bonner-Weir S, Baxter LA, Schuppin GT, Smith FE: A second pathway for regeneration of adult exocrine and endocrine pancreas: a possible recapitulation of embryonic development. Diabetes 1993, 42(12):1715-1720

21. Gu G, Dubauskaite J, Melton DA: Direct evidence for the pancreatic lineage: NGN3+ cells are islet progenitors and are distinct from duct progenitors. Development 2002, 129(10):2447-2457.

22. Lee JE, Hollenberg SM, Snider L, Turner DL, Lipnick N, Weintraub H: Conversion of Xenopus ectoderm into neurons by NeuroD, a basic helix-loop-helix protein. Science 1995, 268(5212):836-844.

23. Naya FJ, Stellrecht CM, Tsai MJ: Tissue-specific regulation of the insulin gene by a novel basic helix-loop-helix transcription factor. Genes Dev 1995, 9(8):1009-1019.

24. Cheng X, Ying L, Lu L, Galvão AM, Mills JA, Lin HC, Kotton DN, Shen SS, Nostro MC, Choi JK, Weiss MJ, French DL, Gadue P: Self-renewing endodermal progenitor lines generated from human pluripotent stem cells. Cell Stem Cell 2012, 10(4):371-384.

doi:10.1186/1475-925X-13-64

Cite this article as: Kuise et al:: Establishment of a pancreatic stem cell line from fibroblast-derived induced pluripotent stem cells. BioMedical Engineering OnLine 2014 13:64. 